\title{
Land cover classification of tundra environments in the Arctic Lena Delta based on Landsat 7 ETM+ data and its application for upscaling of methane emissions
}

\author{
Julia Schneider ${ }^{1}$, Guido Grosse ${ }^{2}$, Dirk Wagner * \\ Alfred Wegener Institute for Polar and Marine Research, Research Unit Potsdam, 14473, Potsdam, Germany
}

\section{A R T I C L E I N F O}

Article history:

Received 2 August 2007

Received in revised form 9 October 2008

Accepted 11 October 2008

\section{Keywords:}

Land cover classification

Methane emission

Upscaling

Tundra environments

Northeast Siberia

Lena River Delta

\begin{abstract}
A B S T R A C T
The Lena River Delta, situated in Northern Siberia $\left(72.0-73.8^{\circ} \mathrm{N}, 122.0-129.5^{\circ} \mathrm{E}\right)$, is the largest Arctic delta and covers $29,000 \mathrm{~km}^{2}$. Since natural deltas are characterised by complex geomorphological patterns and various types of ecosystems, high spatial resolution information on the distribution and extent of the delta environments is necessary for a spatial assessment and accurate quantification of biogeochemical processes as drivers for the emission of greenhouse gases from tundra soils. In this study, the first land cover classification for the entire Lena Delta based on Landsat 7 Enhanced Thematic Mapper (ETM+) images was conducted and used for the quantification of methane emissions from the delta ecosystems on the regional scale. Nine land cover classes of aquatic and terrestrial ecosystems in the wetland dominated (72\%) Lena Delta could be defined by this classification approach. The mean daily methane emission of the entire Lena Delta was calculated with $10.35 \mathrm{mg} \mathrm{CH}_{4} \mathrm{~m}^{-2} \mathrm{~d}^{-1}$. Taking our multi-scale approach into account we find that the methane source strength of certain tundra wetland types is lower than calculated previously on coarser scales.
\end{abstract}

(C) 2008 Elsevier Inc. All rights reserved.

\section{Introduction}

Beside carbon dioxide and water vapour, the atmospheric trace gas methane $\left(\mathrm{CH}_{4}\right)$ is one of the most important greenhouse gases. Methane is chemically very reactive and more efficient in absorbing infrared radiation than carbon dioxide. Its contribution to the radiative forcing from pre-industrial to present time is estimated with about $20 \%$ of all greenhouse gases (IPCC, 2001; Le Mer \& Roger, 2001).

Methane has a wide variety of natural and anthropogenic sources (Wuebbles \& Hayhoe, 2002). Although the major sources of atmospheric methane are relatively well known, the quantification of methane emissions from these sources is difficult due to high spatial and temporal variability (IPCC, 2001). The most important natural sources are wetlands (Bartlett \& Harriss, 1993; Wuebbles \& Hayhoe, 2002). They cover about 4-6\% of the Earth's land surface (Mitsch et al., 1994). $28 \%$ of these wetlands are located in the high latitudes north of $60^{\circ} \mathrm{N}$ in the Arctic and Subarctic climate zone (Matthews \& Fung, 1987). Wetlands emit about $100 \mathrm{Tg}$ methane annually, or about $20 \%$ of overall global emissions of $450-550 \mathrm{Tg} \mathrm{a}^{-1}$ (Matthews, 2000). Estimates of the methane emissions of Arctic and Subarctic wetlands range between 10 and $39 \mathrm{Tg} \mathrm{a}^{-1}$, or between 2.2 and $8.6 \%$ of the overall global methane emissions (Bartlett \& Harriss, 1993; Bartlett et al.,

\footnotetext{
* Corresponding author. Tel.: +49 331288 2159; fax: +49 3312882137. E-mail address: Dirk.Wagner@awi.de (D. Wagner).

${ }^{1}$ Present address: University of Greifswald, Institute of Botany and Landscape Ecology, 17487, Greifswald, Germany.

2 Present address: Geophysical Institute, University of Alaska, Fairbanks, USA.
}

1992). Recently, methane bubbling from thermokarst lakes in ice-rich and organic-rich permafrost regions is included as an additional, previously not considered methane emission source that is increasing the rates of northern wetland methane emission by $10-63 \%$ (Walter et al., 2006).

Biogenic methane emissions from wetlands are determined by two different microbial processes: methane production and methane oxidation (Wagner, 2008). Methane production is mainly controlled by quality of soil organic matter and vegetation; methane oxidation depends strongly on availability of oxygen, while both processes are influenced by soil temperature and pH (Bartlett et al., 1992; Morrissey \& Livingston, 1992; Christensen et al., 1995; Whalen et al., 1996; MacDonald et al., 1998; Wagner et al., 2005). These factors are of high temporal and spatial variability and thus also the $\mathrm{CH}_{4}$ emissions.

Major factors determining the methane emission from Arctic tundra are vegetation, geology, soils and hydrological conditions (Bartlett et al., 1992; Gross et al., 1990; Morrissey \& Livingston, 1992; Christensen et al., 2000). The strong correlation between methane emissions, prevailing vegetation cover, soil moisture is vital for remote sensing based land cover classifications focusing on the quantification of methane emission from tundra wetlands. Extensive field knowledge of individual land cover classes in an investigation area allows the upscaling of methane emission rates from individual study sites to large study regions. Land cover classifications are a standard application for remote sensing data and several global or circumarctic classifications for land cover or vegetation types exist. However, the number of classes, the scale, and the accuracy of these small-scale maps is not sufficient i.e. for remote northern regions (see e.g. Frey \& 
Smith, 2007). In their study, Frey and Smith (2007) demonstrate the very poor accuracy of current coarse-resolution land cover datasets versus a ground truth dataset from the West Siberian lowlands. Major limitations for the satellite-based classifications are coarse-scale satellite data, limited or no ground truth data for very large regions, and a strong generalization of classes. Their finding of exceptionally low accuracies i.e. for wetland and water body classification would pose a fatal error source when trying to estimate methane emissions from regional northern wetlands based on such data. Therefore, we decided to generate our own dataset of recent and high-resolution land cover using high-resolution multispectral data of the Landsat-7 ETM+ sensor for our study area. Within the last 15 years, some studies on land cover classifications utilizing Landsat remote sensing data with different thematic focus have been conducted in Alaska and Canada (Ferguson, 1991; Gross et al., 1990; Joria \& Jorgenson, 1996; Muller et al., 1999; Stow et al., 1998; Brook \& Kenkel, 2002). Land cover classifications of Arctic areas in Russia are rare and most of them have been accomplished within the last years (Rees et al., 2003; Takeuchi et al., 2003; Virtanen et al., 2004; Grosse et al., 2006).

In our study we apply remote sensing techniques for the quantification of methane emission focusing on the tundra region of the Lena Delta in northeast Siberia. The purposes of this study were: (i) to classify the land cover types of the Lena Delta based on their methane emission potential and by using Landsat-7 ETM+ satellite data; (ii) to determine the spatial distribution and coverage of the various land cover classes; (iii) to measure the methane emissions of the major landscape types in the Lena Delta and attribute them to our land cover classes; and (iv) to quantify the methane emissions of the individual land cover classes and of the Lena Delta in total.

With our approach we provide a detailed insight into the land cover and site specific methane emissions of a large, highly heterogeneous tundra wetland landscape in the Arctic and the spatial and temporal upscaling of this data using remote sensing and GIS techniques.

\section{Study area}

The study area is the Lena Delta, located in Northern Siberia at the Laptev Sea coast between the Taimyr Peninsula and the New Siberian Islands (Fig. 1). Occupying an area of about $29,000 \mathrm{~km}^{2}$, it is the largest delta in the Arctic and one of the largest in the world. The delta is characterised by a network of small and large rivers and channels, and more than 1000 islands. The Lena Delta can be divided into three geomorphologically different terraces and active floodplain levels (Are \& Reimnitz, 2000; Schwamborn et al., 2002; Fig. 1). The active floodplain and the first terrace (1-12 $\mathrm{m}$ a.s.l.) are the youngest parts of the Lena Delta. The first terrace was formed during the Middle Holocene and mainly occupies the eastern part of the Lena Delta. It is characterised by the patterned ground of ice-wedge polygons and relatively ice-rich sediments. The second terrace (11-30 m a.s.l.), formed between the Late Pleistocene and Early Holocene occupies about $23 \%$ of the delta and is characterised by sandy sediments with low ice content. The polygonal microrelief is less expressed; thermokarst lake assemblages are typical. The third terrace (30-60 m a.s.l.) is the oldest terrace in the Lena Delta. It is not a fluvial-deltaic unit but an erosional remnant of a Late Pleistocene plain consisting of finegrained, organic-rich and ice-rich sediments that accumulated in front of the Chekanovsky and Kharaulakh mountain ridges in the southern zone of the study area (Schirrmeister et al., 2003). The surface of the third terrace is characterised by polygonal ground and thermokarst processes.

The region is characterised by an Arctic continental climate with low mean annual air temperatures of $-13^{\circ} \mathrm{C}$, a mean temperature in January of $-32^{\circ} \mathrm{C}$, and a mean temperature in July of $6.5^{\circ} \mathrm{C}$. The mean annual precipitation is low and amounts to about $190 \mathrm{~mm}$ (WWIS, 2004). The Lena Delta is located in the zone of continuous permafrost with a thickness of about 500-600 m (Romanovskii \& Hubberten, 2001). The thickness of active layer is usually in the range of $30-50 \mathrm{~cm}$ during summer. The Lena Delta is covered by tundra vegetation of

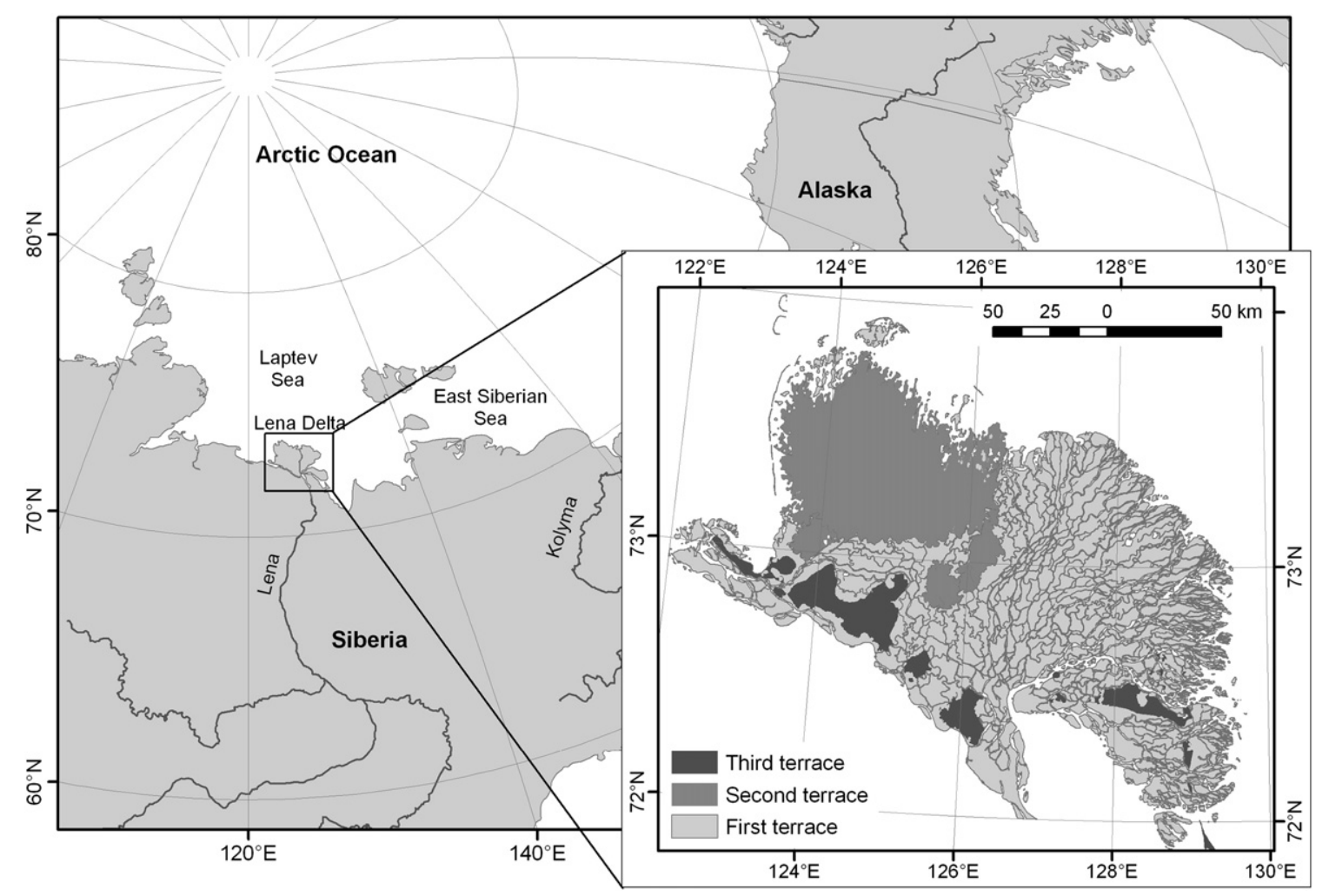

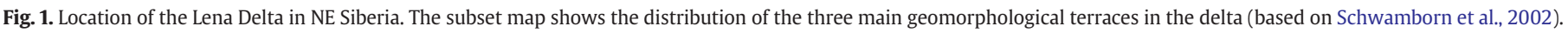


various types. Major components are grasses, sedges, mosses, lichens, herbs, and dwarf shrubs (Kutzbach et al., 2004).

The island Samoylov, situated in the central delta $\left(72^{\circ} 22^{\prime} \mathrm{N}\right.$, $126^{\circ} 29^{\prime} \mathrm{E}$ ), is the main study site for methane emission measurements in the Lena Delta since 1998 (Hubberten et al., 2006). Samoylov covers an area of about $5 \mathrm{~km}^{2}$ and is representative for the first terrace and the floodplains (Boike et al., 2008). The western part of Samoylov is formed by recent fluvial and aeolian processes. Three floodplain levels can be distinguished by inundation frequency and vegetation cover. The sediments are characterised by fine to coarse sands. The Middle Holocene deposits of the first terrace cover about $3 \mathrm{~km}^{2}$ in the eastern part of Samoylov. This area is dominated by active ice-wedge formation, low-centre polygons and small thermokarst ponds. The vegetation and soil patterns are complex due to high lateral variability of the polygonal microrelief consisting of polygon rims and trenches, and polygonal depressions (Kienast \& Tsherkasova, 2001; Kutzbach et al., 2003).

\section{Materials and methods}

\subsection{Image data and processing}

The study was based on land cover classification of three almost cloud free Landsat-7 ETM+ satellite images covering more than 98\% of the Lena Delta. The acquisition dates are 27 July 2000 (path 131, rows 8 and 9) and 26 July 2001 (path 135, row 8). Both were taken approximately at the peak of the vegetation period (snow free months between June to September). ERDAS Imagine ${ }^{\mathrm{TM}}$ software was used to carry out all image processing tasks. In addition to the ETM+ satellite imagery, we acquired and utilized numerous other ancillary data for determination of typical land cover classes and field training sites: vegetation field data, soil information, field and aerial photography.

The three Landsat-7 images were rectified using ground control points from three already orthorectified Landsat-7 ETM+ images (August 2000, path 130, row 9; July 2001, path 133, rows 8 and 9) and by applying a first-order polynomial transformation. The scenes were resampled to $30 \mathrm{~m} \times 30 \mathrm{~m}$ pixels using the nearest neighbour approach. The RMS error was less than 1 pixel, while the base imagery has a horizontal accuracy of approximately $50 \mathrm{~m}$. To minimize radiometric differences between the three scenes due to different atmospheric conditions between two acquisition dates, a basic radiometric and image-based atmospheric correction according to Chavez (1996) was applied. As a result the image digital numbers were converted to reflectance values, the effects of the atmosphere, sun illumination geometry, and instrument calibration on the image data were lowered, and land cover class signatures across the three satellite scenes were normalized. Finally, the three scenes were projected to UTM Zone 52 with the geodetic datum WGS 1984 and a mosaic of the Lena Delta was composed.

Image classifications were conducted using both unsupervised and supervised techniques. Cloud cover was identified by an unsupervised classification and masked out from the image mosaic. The unsupervised classification was also used to identify spectrally similar areas and possible training sites for the supervised classification. The unsupervised ISODATA algorithm was used to derive classifications during a number of classification runs with a varying number of classes ( 6 to 40). However, checking with ground truth data revealed that most of the spectral classes determined in these unsupervised classifications did not represent homogeneous land cover classes. Therefore, a supervised classification was carried out using the spectral bands 1-5 and 7 (VIS, NIR, SWIR). For the supervised classification, the minimum distance algorithm was used, because it can be more effective than the often used maximum likelihood algorithm when the number of training sites per class is limited (Richards \& Jia, 1999). Ancillary data was used to select the training areas for each class, including topographic maps
(1:200,000), a vegetation and soil map (1:1,000,000; Solomonov et al., 1998), a geomorphological map (1:500,000; Grigoriev, 1993), and field knowledge. Our field knowledge comprises almost 10 years of field work in the delta by us and other German and Russian colleagues, resulting in an extensive dataset of geological, geomorphological and biological characteristics, as well as numerous aerial and field photos.

This process resulted in 34 training areas for ten land cover classes. After evaluation of the classes regarding their methane emission two classes were merged. The final number of classes is nine. The size of the training areas varied between $0.09 \mathrm{~km}^{2}$ and $1.6 \mathrm{~km}^{2}$. The training areas were distributed on the active floodplain and first terrace (21 sites), on the second terrace ( 8 sites), and the third terrace (5 sites). The accuracy assessment (e.g. Story \& Congalton, 1986; Congalton, 1991) for our classification was based on 36 validation sites spread over the delta and its terraces. The sites were selected using a random point selection algorithm. As base data for our accuracy assessment we generated an image mosaic of Hexagon satellite images, providing a dataset independent from the Landsat-7 images. The Hexagon satellite series (synonymous with 'Keyhole-9') was part of the United States photographic reconnaissance satellite program and was launched between 1971 and 1986. The satellites carried a photographic mapping camera using 9" film. Almost all imagery was declassified in 2002 and transferred to the United States Geological Survey Earth Resources Observation System (USGS EROS Data Center). Two panchromatic Hexagon images with about $10 \mathrm{~m}$ resolution were acquired over the study area on 16th July 1975 and 9th August 1980. The images were rectified to the Landsat-7 mosaic (all with RMSE smaller than $18 \mathrm{~m}$ ), contrast-stretched, and then merged into a mosaic covering the majority of the delta. Landscape changes between the acquisition dates of Hexagon and Landsat-7 appear to be negligible at the $30 \mathrm{~m}$ Landsat-7 image resolution, except for changes related to differences in the river water level. The validation was further guided by the 1:200,000 topographic maps and field knowledge. The validation sites were classified according to our class scheme and then compared in a correlation matrix to derive an absolute accuracy for our Landsat-7 classification.

\subsection{Methane emission rates and upscaling}

To relate the derived land cover classes with methane emission rates, measurements were carried out in a variety of landscape types in the Lena Delta within the scope of long-term investigations of trace gas emissions during the years 1999 to 2006 . The methane emission rates of these study sites were determined by closed chamber measurements (Wagner et al., 2003). The variation limit of the flux measurements was between 5 and 15\%. Due to the large extent of the study area not all of the identified classes could be studied with emission measurements in the field. For the missing classes we adopted site-specific methane emission rates published in the scientific literature. This method seems appropriate given the good comparability of site characteristics and the type and limited number of classes affected by this approach (basically only lake water classes; see Table 1).

Long-term measurements of more than 1 month have been conducted at various polygonal tundra sites of the first terrace on Samoylov Island and sites located on the lower floodplain. For all other landscape types the methane emission rates are based on a shorter measurement period. Kutzbach and Kurchatova (2002) measured methane emission rates in dry tundra sites of the second terrace of the Lena Delta. We assume that emission rates of other tundra sites with similar dry characteristics are equally low. From the general characteristics of sandy non-vegetated sites we assume also very low methane emission rates nearly zero. This assumption is supported by a measurement of Kutzbach and Kurchatova (2002) at a sandy deflation cliff in the delta. 
Table 1

Mean daily methane emission rates for July and annual emission rates for all land cover classes in the Lena Delta

\begin{tabular}{|c|c|c|c|c|c|c|c|}
\hline \multirow[t]{2}{*}{ Code } & \multirow[t]{2}{*}{ Class } & \multirow{2}{*}{$\frac{\text { Area }}{\mathrm{km}^{2}}$} & \multirow[t]{2}{*}{$\%$} & \multicolumn{2}{|c|}{ Mean daily emission July } & \multicolumn{2}{|c|}{ Annual emission } \\
\hline & & & & $\mathrm{mg} \mathrm{m^{-2 }} \mathrm{d}^{-1}$ & $10^{6} \mathrm{~g} \mathrm{~d}^{-1}$ & $\mathrm{mg} \mathrm{m}^{-2} \mathrm{a}^{-1}$ & $10^{6} \mathrm{~g} \mathrm{a}^{-1}$ \\
\hline$\overline{\mathrm{WT}}$ & Wet sedge- and moss-dominated tundra & 8277 & 28.5 & 16.8 & 139.1 & 1452.3 & $12,020.7$ \\
\hline MT & Moist grass- and moss-dominated tundra & 2173 & 7.5 & 17.2 & 37.4 & 1486.9 & 3231 \\
\hline NV & Non-vegetated areas & 1697 & 5.8 & 0 & 0 & 0 & 0 \\
\hline MDD & Moist to dry dwarf shrub-dominated tundra & 1832 & 6.3 & $58.4^{\mathrm{a}}$ & 107 & 5048.5 & 9248.9 \\
\hline DMSD & Dry moss-, sedge- and dwarf shrub-dominated tundra & 3519 & 12.1 & $0.4^{\mathrm{b}}$ & 1.4 & 34.6 & 121.8 \\
\hline DG & Dry grass-dominated tundra & 610 & 2.1 & $0.4^{\mathrm{b}}$ & 0.2 & 34.6 & 21.1 \\
\hline DT & Dry tussock tundra & 444 & 1.5 & $0.4^{\mathrm{b}}$ & 0.2 & 34.6 & 15.4 \\
\hline \multirow[t]{5}{*}{ WB } & Water bodies & 8894 & 30.6 & & & & \\
\hline & Rivers and coastal waters & 5886 & 66.2 & $0^{c}$ & 0 & 0 & 0 \\
\hline & Lakes ( $>0.36$ ha $=4$ Landsat-7 pixel) & $3008^{d}$ & 33.8 & & & & \\
\hline & Thermokarst lakes on 3rd terrace & $88.9^{\mathrm{d}}$ & 3.0 & - & - & $24,900^{\mathrm{e}}$ & $2213.6^{\mathrm{e}}$ \\
\hline & All other lakes & $2919.1^{\mathrm{d}}$ & 97.0 & $3.1^{\mathrm{f}}$ & 9.0 & 268 & 782.3 \\
\hline \multirow[t]{4}{*}{ SW } & Shallow water & 1590 & 5.5 & & & & \\
\hline & Vegetated lake margins and shoals & 159 & $10^{g}$ & $40.3^{\mathrm{h}}$ & 6.4 & 3483.8 & 553.9 \\
\hline & Sandbanks and shoals in rivers and along the coast & 1431 & $90^{\mathrm{g}}$ & 0 & 0 & 0 & 0 \\
\hline & Total & 29,036 & 100 & $10.35^{\mathrm{i}}$ & $300.7^{\mathrm{i}}$ & 972.14 & $28,208.7$ \\
\hline
\end{tabular}

\footnotetext{
a Values for class MDD measured in June.

b Values adopted from Kutzbach and Kurchatova (2002); measured in the Lena Delta. set these emissions to zero.

d Area of lakes based on Morgenstern (2005).

e Value adopted from Walter et al. (2006); measurements cover the whole annual cycle, incl. winter emissions; measured in NE Siberia.

${ }^{f}$ Value adopted from Morrissey and Livingston (1992); measured in Alaskan North Slope region.

g Percentage ratio between subclasses is based on visual interpretation of the classification image and the Landsat 7 data.

h Values from this study, Wagner et al. (2003), and Spott (2003); all measured in the Lena Delta.

${ }^{\mathrm{i}}$ Daily emissions of thermokarst lakes are not included.
}

c According to Semiletov (1999) methane concentrations in the Lena Delta channels and offshore waters were close to his analytical measurement limit $(<0.015 \mu \mathrm{M} / \mathrm{l})$. We therefore

The assignment of methane emission rates to water habitats is more challenging because of the strong diversity of water bodies in the delta (coastal waters, rivers, and lakes) and their very different emission characteristics depending on genesis, hydrological properties, cryolithological setting, size, and depth. The area in the delta covered by water bodies is nearly $8900 \mathrm{~km}^{2}$, and according to Morgenstern (2005) lakes $>0.36$ ha occupy about $3008 \mathrm{~km}^{2}$ or $33.8 \%$ of the water surfaces. High emission rates can be expected from most shallow water areas occurring as vegetated lake margins and shoals. On the contrary, non-vegetated shoals and sandbanks in rivers, lakes and along the coast are likely to have very low methane emission rates. From a visual interpretation of the classification and the Landsat-7 data we estimate that about $90 \%$ of the shallow water areas consist of sandbanks in the river channels and on the coast, and only about $10 \%$ are vegetated lake margins.

Methane emission rates for the delta channels and offshore areas are more difficult to estimate due to the dynamic fluvial environment. According to measurements by Semiletov (1999), rivers and coastal waters around the Lena Delta had methane concentrations below his analytical measurement limit $(<0.015 \mu \mathrm{M} / \mathrm{l})$ and thus appear to emit only traces at best. Therefore we consider emissions from these areas negligible when compared to terrestrial emissions from the delta. Therefore, only the methane emission rates of the lakes are included in our balance. There are different types of lakes in the delta in terms of lake genesis and substrate. Due to lacking measurements of the methane emission rates of the various lake types in the Lena Delta, we adopted rates measured for comparable lakes in Alaska north of $68^{\circ} \mathrm{N}$ by Morrissey and Livingston (1992). We are aware that especially thermokarst lakes located in ice-rich and organic-rich substrates, as they are exist on the third terrace of the delta, are a large source for methane emissions by decomposition of old Pleistocene carbon and subsequent methane ebullition. Therefore, we adopted values for this kind of thermokarst lakes in the Lena Delta from similar lakes in NE Siberia (Walter et al., 2006).

Table 1 shows the methane emission rates we used for the calculation of the methane emissions of the Lena Delta. These are the mean values measured in July; only the rates for the land cover class moist to dry dwarf shrub-dominated tundra (MDD) have been measured in June.
The daily methane emission of the entire Lena Delta is a sum of the methane emissions from all individual classes, which in turn are products of the area of the individual class and the daily methane emission rate for this class.

To upscale methane emissions from classes with limited field measurements we developed a ratio-based method. We calculated the ratio of June-October versus July emissions for the extensively studied class wet sedge- and moss dominated tundra (WT), assuming that this ratio is a basic characteristic of the seasonal cycle of methane emissions in the region and is also valid for other land cover classes. Then we used the ratio to upscale methane emissions from classes with short measurement periods towards the full June-October period.

The annual methane emission of the Lena Delta area is a sum of the emissions from all land cover classes, which in turn are the product of the area of the individual class and the methane emission rate of each class within the period from June to October. Based on our measurements in early winter (Oct. 2003), we assume that the methane emission in winter is about zero (Ganzert et al., 2004). Although methane is still produced at sub-zero temperatures by microorganisms, this methane can not diffuse through the frozen ground and will be trapped into the frozen sediments until the next spring (Wagner et al., 2007). However, based on values adopted from Walter et al. (2006) we include the methane produced during winter in deep thermokarst lakes located in ice-rich and organic-rich permafrost, which is then released in spring.

\section{Results}

\subsection{Supervised classification}

Nine land cover classes characterised by their vegetation, surface moisture, and topography plus one cloud mask class could be defined for the Lena Delta area:

Wet sedge- and moss-dominated tundra (WT): sites with watersaturated substrate and a nearly continuous cover of sedges, especially Carex aquatilis, and other hydrophilic graminoids growing in shallow water (e.g. Eriophorum scheuchzeri) or mosses (Fig. 2f). 

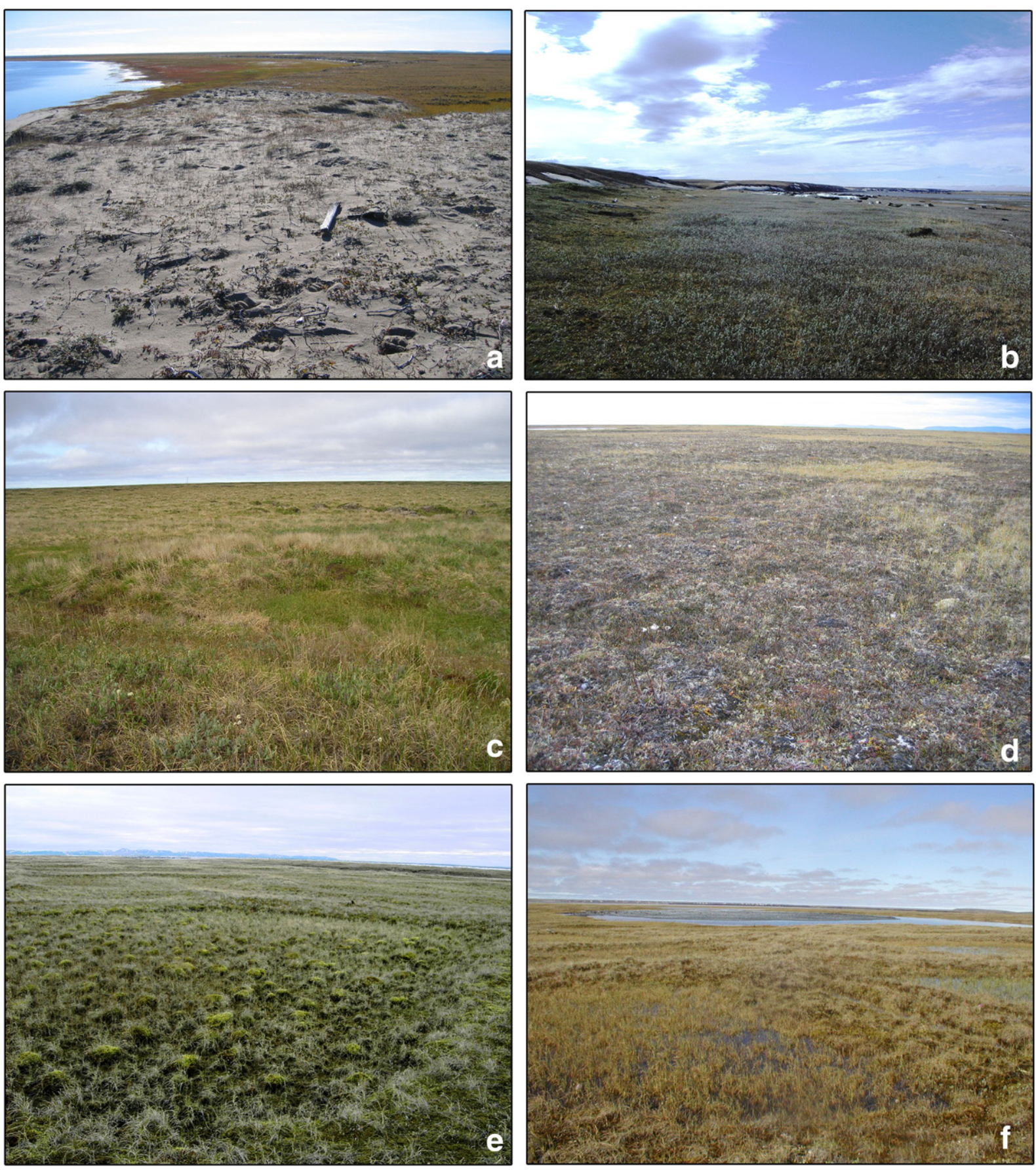

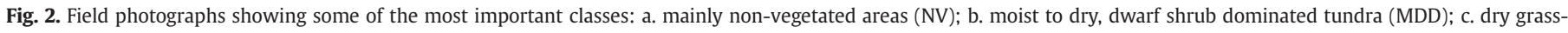

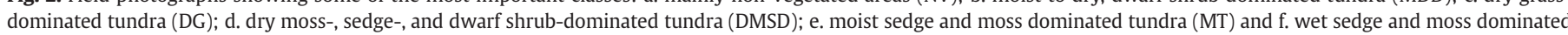
tundra (WT; photos AWI).

Moist grass- and moss-dominated tundra (MT): areas are characterised by moist tundra on poorly drained soils and a continuous vegetation cover of grasses, mosses and dwarf shrubs (Betula nana, Salix spp.; Fig. 2e).

Moist to dry dwarf shrub-dominated tundra (MDD): this class is dominated by dwarf shrubs and is found on moist to dry sites. It occupies large areas of the lower floodplain and is dominated by dwarf willows; on moist sites cotton grass occurs. Seasonal inundations of these areas result in a high content of nutrients in the soils and a dense vegetation cover (Fig. 2b).
Dry moss-, sedge- and dwarf shrub-dominated tundra (DMSD): well drained sites with sand as predominant substrate, found often close to cliffs. The vegetation cover can vary: there are sites dominated by sedges, and cotton grass and mosses as dominant vegetation with isolated occurring lichens and dwarf shrubs, other sites are dominated by dwarf shrubs and lichens (Fig. 2d).

Dry grass-dominated tundra (DG): this cover type occurs predominantly on the lower floodplain, the substrates are mostly dry and temporary moist after the inundation. The areas are 
characterised by grasses (e.g. Deschampsia brevifolia), some sites are only sparsely vegetated (Fig. 2c).

Dry tussock tundra (DT): this land cover class is characteristic for dry, very well-drained sites of upper slopes and pingos. The vegetation cover consists of Eriophorum vaginatum tussocks.

Mainly non-vegetated areas (NV): barren or partially vegetated areas on active river bars, along the coast line, or deflation cliffs. These sites are mostly sandy and vary in soil moisture (Fig. 2a).

Shallow water (SW): this class consists of shallow recurrent or steadily inundated areas: a) shallow coastal waters including intertidal areas, shallow waters of riverbanks, and mainly barren sand bars, or b) shallow parts of lakes and rivers with typical partially submerged vegetation of sedges and hydrophilic grasses. Water bodies (WB): water bodies include the open water of lakes, rivers, streams and coastal waters.

Cloud mask: clouds and cloud shadows.

Notably, the land cover classification reflects the different terraces and floodplains of the Lena Delta (Fig. 3). Nearly one third of the total area of the Lena Delta is occupied by water bodies (WB 30.6\%; Table 1). Together with the land cover classes SW (5.5\%), WT (28.5\%) and MT (7.5\%) the wetland classes amount to $72.1 \%$ of the Lena Delta area, indicating the dominance and importance of wetland areas for the

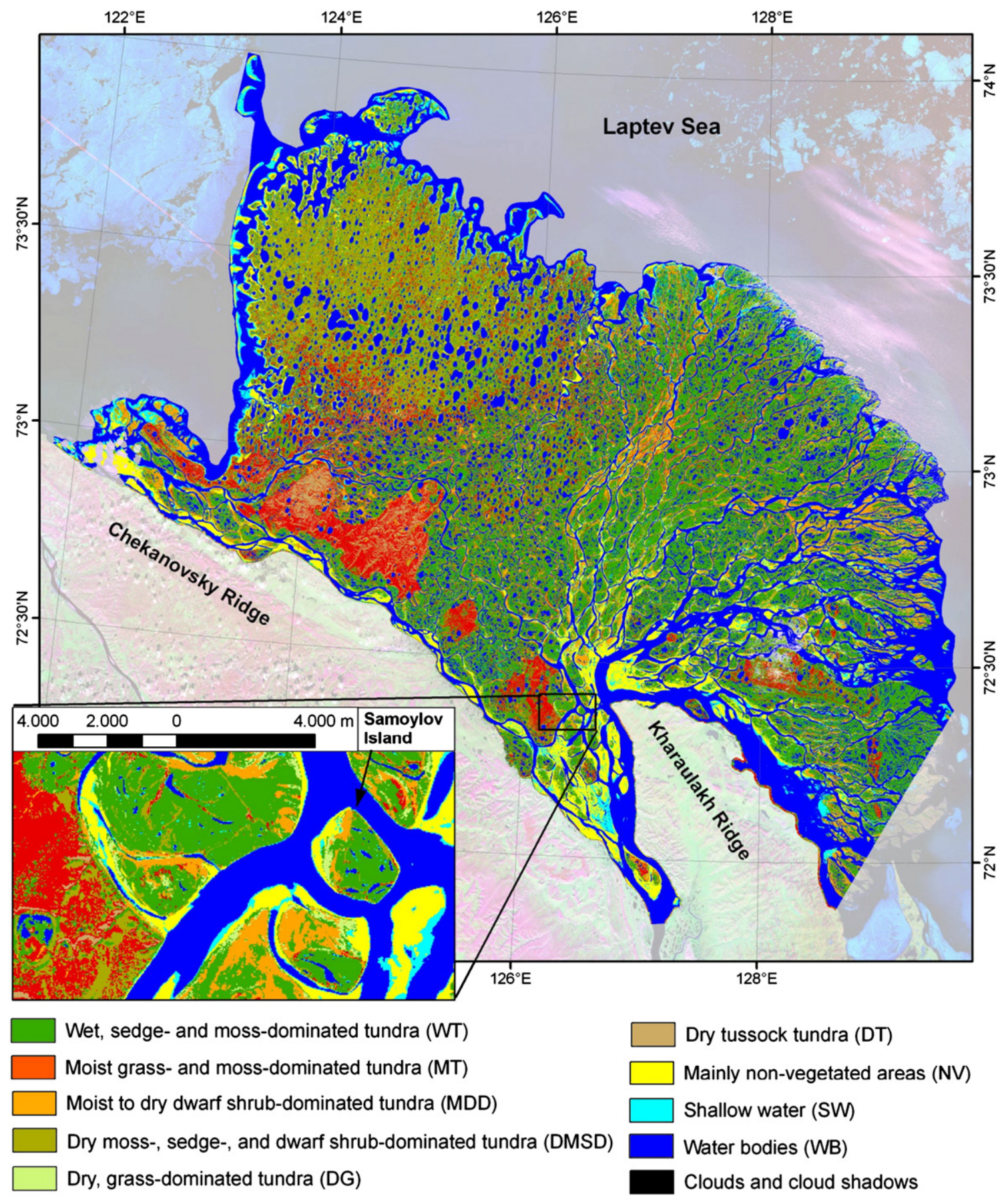

Fig. 3. Supervised classification of the Lena Delta and detailed subset showing the class distribution around Samoylov Island in the central delta. 
delta ecosystem. The composition and distribution of non-water cover classes strongly varies for the three main river terraces. Whereas the first and the third terrace are dominated by moist to wet classes, the second terrace is dominated by classes indicating mainly dry conditions. The first terrace is mainly composed of WT and MT, but classes related to active fluvial processes are also abundant (especially classes NV and SW in the delta apex area and along the major channels). The second terrace is clearly dominated by the class DMSD, with some WT and MT in thermokarst basins, and MDD in the southern part of the terrace. The third terrace is characterised by the MT and DT mainly in the thermokarst valleys but also on the plateau.

\subsection{Upscaling of methane emissions: case study for the land cover class} wet sedge- and moss-dominated tundra (WT)

Within the scope of this study the most detailed measurements were done for the land cover class wet sedge- and moss-dominated tundra (WT). There are several reasons for concentrating on the detailed and systematic investigation of the methane emissions from this class. First, from our previous measurement campaigns we know that this land cover class is the most important source of methane in the Lena Delta. Second, extensive ancillary data about the soil composition, soil moisture, soil physics, vegetation, microrelief, and microbiology are available for the systematic investigation of the determining factors for methane emission (Fiedler et al., 2004; Kutzbach et al., 2004; Wagner et al., 2005; Liebner and Wagner, 2007). Third, a high-grade long-term dataset based on daily summer methane emission measurements from two representative areas within this class were available for our calculations (e.g. Wagner et al., 2003). These preconditions allow the investigation of small-scale heterogeneities of important parameters and their influence on the methane emission from this individual land cover class. The land cover class WT consists of polygonal microrelief and lakes of different sizes with high emission rates in wet polygon centres and the vegetated lake margins, and lower emission rates from drier polygon rims and open water ponds. Therefore, we determined methane emission rates for this class at a sub-class scale by doing separate measurements for the various microrelief and water body features (Table 2). An overevaluation of extreme flux events, which can lead to a significant error in the up-scaling, could be largely excluded based on the available long-term flux record for this class. Supervised classification of helicopter-borne, visible wavelength aerial imagery (ca. $0.3 \mathrm{~m}$ ground resolution) was used to assess the percentage coverage for each subclass in the class WT on Samoylov Island. The weighted calculation shows that methane emission rates of this class range from 10.8 to $23.3 \mathrm{mg} \mathrm{CH}_{4} \mathrm{~m}^{-2} \mathrm{~d}^{-1}$, with a mean at $16.8 \mathrm{mg} \mathrm{CH}_{4} \mathrm{~m}^{-2} \mathrm{~d}^{-1}$ in July.

\section{Table 2}

Daily methane emission rates measured in different sub-classes of the land cover class WT (wet sedge- and moss-dominated tundra) in the months June to October

\begin{tabular}{|c|c|c|c|c|c|c|c|}
\hline \multirow[t]{2}{*}{ Sub-class } & \multirow{2}{*}{$\begin{array}{l}\text { Cover } \\
(\%)\end{array}$} & & \multicolumn{5}{|c|}{ Methane emission $\left(\mathrm{mg} \mathrm{CH}_{4} \mathrm{~m}^{-2} \mathrm{~d}^{-1}\right)$} \\
\hline & & & June & July & August & September & October \\
\hline \multirow[t]{3}{*}{ Very wet sites } & 7.8 & Mean & 54.1 & 93.7 & 44 & 17.9 & 11.2 \\
\hline & & Min & 13.7 & 60.3 & 32.9 & 7.0 & 2.3 \\
\hline & & Max & 89.4 & 119.6 & 72.6 & 25.8 & 25.3 \\
\hline \multirow[t]{3}{*}{ Dry sites } & 62.2 & Mean & 2.5 & 4.7 & 6.1 & 2.1 & 1.7 \\
\hline & & Min & 0.7 & 3.3 & 3.1 & 0.6 & 0.7 \\
\hline & & Max & 4.6 & 6.2 & 11.4 & 4.0 & 3.9 \\
\hline \multirow[t]{3}{*}{ Water } & 15.2 & Mean & n.d. & $4.1^{\mathrm{a}}$ & $7.9^{\mathrm{a}}$ & n.d. & n.d. \\
\hline & & Min & n.d. & $2.0^{\mathrm{a}}$ & $3.3^{\mathrm{a}}$ & n.d. & n.d. \\
\hline & & Max & n.d. & $7.9^{\mathrm{a}}$ & $15.7^{\mathrm{a}}$ & n.d. & n.d. \\
\hline \multirow[t]{3}{*}{ Overgrown water } & 14.8 & Mean & n.d. & $40.3^{a}$ & $48.1^{\mathrm{a}}$ & n.d. & n.d. \\
\hline & & Min & n.d. & $25.6^{a}$ & $31.9^{\mathrm{a}}$ & n.d. & n.d. \\
\hline & & Max & n.d. & $59.9^{a}$ & $67.1^{\mathrm{a}}$ & n.d. & n.d. \\
\hline
\end{tabular}

The percentage of sub-class cover was determined by aerial image analysis of key sites on the first delta terrace.

n.d.-not determined.

a Values from Spott (2003).
Table 3

Methane emissions of the land cover class WT (wet sedge- and moss-dominated tundra) in the months June to October (weighted calculation)

\begin{tabular}{lrlcll}
\hline \multirow{2}{*}{$\begin{array}{l}\text { Wet sedge- and } \\
\text { moss-dominated tundra }\end{array}$} & \multicolumn{5}{c}{ Methane emission $\left(\mathrm{mg} \mathrm{CH}_{4} \mathrm{~m}^{-2} \mathrm{~d}^{-1}\right)$} \\
\cline { 2 - 6 } & June $^{\mathrm{a}}$ & July & August & September $^{\mathrm{a}}$ & October $^{\mathrm{a}}$ \\
\hline Mean & 8.25 & 16.82 & 15.55 & 3.86 & 2.76 \\
Minimum & 2.15 & 10.84 & 9.72 & 1.31 & 0.88 \\
Maximum & 14.05 & 23.25 & 25.07 & 6.43 & 6.28 \\
\hline
\end{tabular}

a Due to missing values for the sub-classes 'water' and 'overgrown water' the weighted calculation is based only on values for the sub-class types 'very wet sites' and 'dry sites'.

Temporal variations during the vegetation period are another central objective of long-term investigation of methane emissions in the Lena Delta. While methane emission rates for the polygon rims and centres have been determined in the field for the period from June to October, the rates for the open water and vegetated rims of lakes have been determined only in July and August. We conducted a weighted calculation of the methane emission rates for the different months for this land cover class (Table 3).

\subsection{Upscaling of methane emissions in the Lena Delta}

The methane emission rates vary strongly among the individual land cover classes. While the highest amounts are emitted by the class MDD, followed by the vegetated lake margins and the classes MT and WT, the lowest rates are emitted by the classes with dry substrate characteristics (DMSD, DG, and DT; Table 1). The land cover classes WT and MT represent the wetlands of the Lena Delta. The methane emission rate of these wetlands is $16.8 \mathrm{mg} \mathrm{CH}_{4} \mathrm{~m}^{-2} \mathrm{~d}^{-1}$ (weighted calculation). The daily methane emission of the entire Lena Delta was calculated with $300.7 \times 10^{6} \mathrm{~g}$ (standard error $<15 \%$; Table 1).

Based on our measurements we calculated temporal trends of methane emissions for the class WT (Table 3). In the data we observe a fast increase of emissions in June, then a maximum in July, and the slow decrease of methane emission rates in the following months. The total methane emission of the class WT for the measurement period from June-October (153 days) amounts to $1452 \mathrm{mg} \mathrm{CH} \mathrm{m}^{-2}$. The calculation of the methane emissions from all other land cover classes during the vegetation period is based on the ratio of the methane emissions of each individual land cover class and the methane emission of the class WT.

The upscaling of emissions for the Lena Delta is a weighted calculation using the methane emission rates of the individual classes (Table 1). The highest amounts of methane are emitted by the classes WT $\left(12 \times 10^{9} \mathrm{~g} \mathrm{CH}_{4}\right.$ per year) and $\operatorname{MDD}\left(9.2 \times 10^{9} \mathrm{~g} \mathrm{CH}_{4}\right.$ per year $)$, followed by MT $\left(3.2 \times 10^{9} \mathrm{~g} \mathrm{CH}_{4}\right.$ per year). The various "dry" tundra classes cover a large area of the Lena Delta and their contribution to the total methane emission of the delta is very low $\left(0.2 \times 10^{9} \mathrm{~g} \mathrm{CH}_{4}\right.$ per year) compared to the "moist" and "wet" tundra classes.

\section{Discussion}

\subsection{Land cover classification}

A common method for a general land cover classification of large heterogeneous datasets is the automatic unsupervised classification based on a chain algorithm and the subsequent labelling of land cover classes with real land cover features (Joria \& Jorgenson, 1996; Stow et al., 1998; Cihlar, 2000). Such unsupervised classifications with a very large number of classes proved unsuitable for the land cover classification of wetlands with a focus on methane balancing, as usually only a limited number of measurement sites are available. Furthermore, the classes obtained with such an unsupervised approach are ecologically very heterogeneous and thus unsuitable 
Table 4

Error matrix, user's, producer's and overall accuracy for supervised classification of the Lena Delta

\begin{tabular}{|c|c|c|c|c|c|c|c|c|c|c|}
\hline & \multicolumn{10}{|l|}{ Reference data } \\
\hline & & WT & MT & MDD & DMDS & NV & SW & WB & Total & User's accuracy (\%) \\
\hline \multirow[t]{11}{*}{ Classified data } & WT & 4 & 1 & 1 & & & & 1 & 7 & 57.1 \\
\hline & MT & & 2 & 1 & & & & & 3 & 66.7 \\
\hline & MDD & & & 3 & & 1 & 1 & & 5 & 60 \\
\hline & DMDS & & & 1 & 5 & & & & 6 & 83.3 \\
\hline & NV & & & & & 5 & & & 5 & 100 \\
\hline & SW & 1 & & & & & 4 & & 5 & 80 \\
\hline & WB & & & & & & & 5 & 4 & 100 \\
\hline & Total & 5 & 3 & 6 & 5 & 6 & 5 & 6 & 36 & \\
\hline & Producer's accuracy (\%) & 80 & 66.7 & 50 & 100 & 83.3 & 80 & 83.3 & & \\
\hline & Overall accuracy (\%) & & & & & 77.8 & & & & \\
\hline & $\kappa$ & & & & & 0.74 & & & & \\
\hline
\end{tabular}

for the upscaling of local datasets. Thus, we used a supervised classification approach based on a relatively small number of classes for the classification of the Lena Delta. We obtained the best results with the supervised minimum distance algorithm using nine classes. The Landsat 7 derived classes reflect especially the local soil moisture and vegetation conditions, both important parameters for the methane emissions of a site (MacDonald et al., 1998; Wagner et al., 2003; Kutzbach et al., 2004). Therefore, the land cover classes could be related to locally measured methane emissions.

Within this study we used class area calculations based on the land cover classification of a Landsat 7 image mosaic from July 2000 and 2001. This mosaic provides a snapshot of the mid-summer situation in the highly dynamic environment of the Lena Delta. Seasonal variations, like changes in vegetation cover density, soil moisture, or the annual inundation of the floodplain levels during spring flood, are currently not considered in our calculations. However, by carefully characterizing and choosing classes based not only on vegetation but also on geomorphological and hydrological properties we can strongly decrease possible temporal heterogeneities in the classification.

The accuracy assessment based on the Hexagon satellite images indicated an overall relative accuracy of $66.7 \%$. A first error matrix indicated accuracies for individual classes ranging from 20 to $100 \%$ (data not shown). The poorest producers' accuracy of $20 \%$ was achieved for the class SW which was frequently misclassified as WB. This is related to the fact that there is a temporal difference between the classified dataset and the validation dataset, resulting in different water levels and thus an erroneous accuracy assessment for shallow water classes. However, it is usually not difficult to spectrally separate water classes from other land cover, and also to differentiate between deep and shallow water using Landsat-7 data. By visually checking the questionable SW and WB validation sites in the Landsat-7 data we found that our Landsat-7 classification was correct and could adjust our validation dataset accordingly. These results were now included into the final error matrix (Table 4). Our accuracy assessment of the Landsat-7 supervised classification indicates a reasonable well overall accuracy of $77.8 \%$ (Kappa $=0.74$ ) for such a large and remote study area. Relative accuracies for individual classes ranged from 50 to $100 \%$. Misclassifications usually occurred within neighboring classes with higher similarity in environmental parameters (e.g. between WT and MT). A considerable uncertainty is left in this relative accuracy assessment because the Hexagon-based reference data may not be more reliable than the Landsat-derived land cover maps.

Despite the described challenges, we were able to classify the land cover of the Lena Delta and to relate these classes to methane emission rates based on currently available field data. This land cover classification is the first encompassing the entire Lena Delta at high resolution.

\subsection{Case study for the land cover class wet sedge- and moss-dominated tundra (WT)}

The small-scaled heterogeneity of vegetation cover, soils and water balance in the Lena Delta have a direct effect on the methanogenesis and the amount of the emitted methane. The most detailed balance of methane emissions could be realised for the land cover class WT. It mostly consists of typical polygonal tundra and covers large areas of the Lena Delta. We demonstrated that drier sites consisting of polygon rims dominate the polygonal tundra, covering nearly $62 \%$ of this class.

Bartlett et al. (1992) and Christensen et al. (1995) measured lower methane emissions for dry tundra sites in polygonal tundra than in this study (Table 5). The mean daily methane emission rates of the polygonal lakes of the Lena Delta are within the range of the methane emissions from polygonal lakes at other study sites (Table 5). The importance of lakes for the methane emissions from tundra and the

Table 5

Methane emission [ $\mathrm{mg} \mathrm{CH}_{4} \mathrm{~m}^{-2} \mathrm{~d}^{-1}$ ] of various sub-classes in different studies

\begin{tabular}{|c|c|c|c|c|c|c|}
\hline Sub-class region & $\begin{array}{l}\text { Wet polygon } \\
\text { centres }\end{array}$ & $\begin{array}{l}\text { Polygon rims and } \\
\text { other dry sites }\end{array}$ & $\begin{array}{l}\text { Polygonal } \\
\text { lakes }\end{array}$ & $\begin{array}{l}\text { Vegetated } \\
\text { lake margins }\end{array}$ & Tussock tundra & Reference \\
\hline Northeast Siberia, Lena Delta & 93.7 & 4.7 & 4.1 & 40.3 & - & This study, Wagner et al. (2003), Spott (2003) \\
\hline Yukon-Kuskokwim Delta, Alaska & $144 \pm 31$ & $2.3 \pm 1.1$ & $0.4-16$ & 89 & - & Bartlett et al. (1992) \\
\hline Siberian and European tundra & $46.8 \pm 5.9$ & $2.3 \pm 0.7$ & - & - & - & Christensen et al. (1995) \\
\hline North Slope of Alaska & 90 & - & 21 & - & - & Whalen and Reeburgh (1990) \\
\hline North Slope of Alaska & - & - & $1.28-16.32$ & - & - & Kling et al. (1992) \\
\hline North Siberia & - & - & $7.6 \pm 1.3$ & - & - & Zimov et al. (1997) \\
\hline North Slope of Alaska & - & - & 3.1 & 79.3 & - & Morrissey and Livingston (1992) \\
\hline Northeastern Siberia & 290 & - & - & - & - & Nakano et al. (2000) \\
\hline Northeastern Siberia & - & - & - & - & $195.8 \pm 80.7$ & Corradi et al. (2005) \\
\hline \multirow[t]{3}{*}{ Northeastern Siberia } & $7.92 \pm 3.6(2004)$ & & & & $-0.48 \pm 0.24(2004)$ & Van der Molen et al. (2007) \\
\hline & $1.2 \pm 1.92(2005)$ & - & - & - & $0.24 \pm 0.00(2005)$ & \\
\hline & $5.28 \pm 4.8(2006)$ & & & & $-4.32 \pm 1.44(2006)$ & \\
\hline
\end{tabular}


global methane emissions is not yet sufficiently clarified. According to Semiletov et al. (1996), the limnic ecosystems of the tundra are one of the most important recent methane sources to the atmosphere. This is confirmed by a study of Walter et al. (2006) focusing on the ebullition of methane from thermokarst lakes. On the contrary, Morrissey and Livingston (1992) determined that lakes have a considerably lower methane emission potential than other sites in the tundra. Bartlett et al. (1992) suggest a close connection between methane emissions and the size of the lakes. Small lakes (less than $10 \mathrm{~km}^{2}$ ) emit significantly more methane than the large lakes (more than $10 \mathrm{~km}^{2}$ ). In contrary, Kling et al. (1992) reported in their study that there is no correlation between the methane emission of a lake and its size, depth, or its latitudinal location. For deep thermokarst lakes the frozen sediment, in which they are growing, and sediment carbon content are important factors for their methane emission potential. Icy and organic-rich sediments can provide additional old carbon for methanogenesis in these thaw lakes resulting in higher emissions (Zimov et al., 1997). However, the importance of the vegetated lake margins for the methane balance of the tundra is well known. The mean daily methane emissions estimated by Bartlett et al. (1992) and Morrissey and Livingston (1992) amount double the methane emissions of vegetated lake margins in our study. Differences in methane emissions between these studies appear largely due to differences in the location of the study sites and the individual site and lake characteristics. The correlation between temperature and the plant mediated transport of methane in the vegetated lake margins determined by King et al. (1998) can be an explanation for higher methane emissions of vegetated lake margins found by Bartlett et al. (1992) and Morrissey and Livingston (1992) comparing to the results of this study.

The mean daily methane emission rate of wet polygon centres in the Lena Delta is $93.7 \mathrm{mg} \mathrm{CH}_{4} \mathrm{~m}^{-2} \mathrm{~d}^{-1}$ (Table 5). Rates about one third higher were measured by Bartlett et al. (1992) at wet meadow sites, and nearly half of this rate by Christensen et al. (1995) at wet tundra sites. Both sites are comparable to the sites in the Lena Delta because these sites are also characterised by water saturated soils and vegetation of Carex spp. and Eriophorum spp. The measurements in the Lena Delta and those of Whalen and Reeburgh (1990) at wet tundra sites are highly consistent. The methane emissions reported by Nakano et al. (2000) for water saturated sites in the tundra are much higher than the methane emissions in our study. Differences between the measurements appear also due to the different length of the investigation period. If the study period is short, the methane emissions strongly reflect short-term weather conditions (Christensen, 1993). In our study the methane emission rates have been measured during field trips of several weeks since 1998. Summarizing, the differences in methane emission at different study sites are obvious, and the measured methane emissions from the various subclasses of the land cover class WT in the Lena Delta are within the range of those reported from analogous areas in the high latitudes.

The mean daily methane emission of the class WT amounts to $16.8 \mathrm{mg} \mathrm{CH} \mathrm{m}^{-2} \mathrm{~d}^{-1}$. The high emission rates of the wet polygon centres are not reflected in the emission of this class due to the low percentage (7.8\%) of the area of this particular sub-class type in this class. In contrast, the low methane emissions of the drier sub-class and the lakes have a strong influence on the total amount of methane emission from this class.

Generally, the length of the measurement period is an important factor for the quality and the applicability of measured methane emission rates for temporal and spatial upscaling. Most of the previous studies were conducted during July and August only (Whalen \& Reeburgh, 1990; Bartlett et al., 1992; Martens et al., 1992; Christensen et al., 1995). Some provide only imprecise information about the investigation period (Morrissey \& Livingston, 1992; Nakano et al., 2000; Takeuchi et al., 2003). This also results in difficulties when comparing these methane emission rates to our long-term multi-annual measurements of the class WT. A study by Christensen et al. (2000) covering an investigation period from the middle of June to the end of August is an exception. Their study covers the high-arctic Zackenberg Valley in Greenland, which strongly differs in climatic and substrate conditions to the sites in the Lena Delta. In Zackenberg Valley, the fast increase of the emissions at the beginning of the vegetation period is missing and the methane emission is nearly zero $\mathrm{mg} \mathrm{CH}_{4} \mathrm{~m}^{-2} \mathrm{~d}^{-1}$ in June. Methane emission rates throughout the year are considerably lower than in the Lena Delta.

\subsection{Upscaling of methane emissions in the Lena Delta}

The local-scale heterogeneity in vegetation and soil moisture and, thus, in methane emission was analysed only within the land cover class WT. The coverage of this class in the Lena Delta is $28.5 \%$ and the percentage of methane emission is $42.6 \%$ (Fig. 4). The small-scaled mosaic of the class MT could not be investigated with the same level of detail. The coverage of this class in the Lena Delta is $7.5 \%$ and the percentage of methane emission is about $11.5 \%$ (Fig. 4). In this study, the land cover class MDD emits $32.8 \%$ of the methane in the Lena Delta but covers only $6.3 \%$ of the delta (Fig. 4 ). Although the vegetated lake margins cover only $0.55 \%$ of the Lena Delta area, they contribute to $2 \%$ of the delta emissions.

Methane emission rates of rivers in the Lena Delta are estimated to be low. Results of Heikkinen et al. (2004) and Whalen and Reeburgh

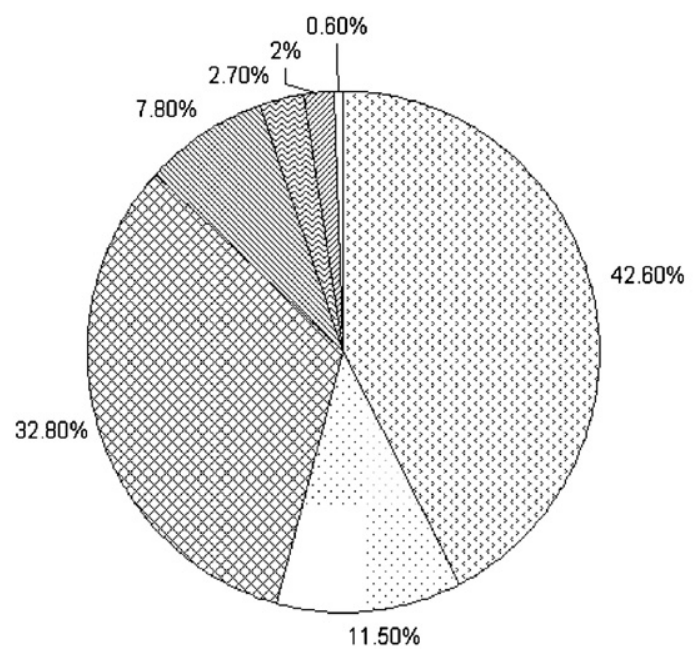

Wet sedge- and moss-dominated tundra

Moist grass- and moss-dominated tundra

Moist to dry dwarf shrub-dominated tundra

Thermokarst lakes

All other lakes

Vegetated lake margins

Dry moss-, sedge- and dwarf shrub-dominated tundra, Dry grass-dominated tundra, Dry tussock tundra

Fig. 4. Percentage of methane emissions of individual land cover classes based on the total methane emission of the Lena Delta. 
(1990) indicate that arctic rivers and thermokarst lakes are important methane sources. However, a study of $\mathrm{CH}_{4}$ in the surface waters of the Lena Delta by Semiletov et al. (1996) shows that the rivers and coastal waters are not significant factors in the present methane budget of the Lena Delta area. Thermokarst lakes are with $7.8 \%$ of the total emission important contributors to the annual methane emissions of the Lena Delta. Their importance becomes obvious comparing their annual emission to those of all other lakes. Only 3\% of all lakes are thermokarst lakes in ice-rich and organic-rich permafrost, but they probably emit nearly the 3-fold of the methane emission of all other lakes within the Lena Delta. Although the open water areas cover 30\% of the Lena Delta, their total share on the methane emission is only $10.5 \%$ (Fig. 4).

Compared to the methane emissions measured by Corradi et al. (2005) at tussock sites of the Kolyma river floodplain the mean daily methane emissions $\left(0.4 \mathrm{mg} \mathrm{CH}_{4} \mathrm{~m}^{-2} \mathrm{~d}^{-1}\right)$ of dry tussock sites in the Lena Delta are relatively low but they are well within the range of the methane emission reported by Van der Molen et al. (2007; Table 5). According to Heikkinen et al. (2004), the methane emission rates of dry sites are in general very low or negative. In the Lek Vorkuta catchment they estimated methane emissions between -8.1 and $10.5 \mathrm{mg} \mathrm{CH}_{4} \mathrm{~m}^{-2} \mathrm{~d}^{-1}$, averaging around zero. The more dry sites cover nearly $15 \%$ of the delta area, and their methane emission amounts to only $0.6 \%$ of the total Lena Delta emission (Fig. 4).

The mean daily methane emission of the Lena Delta is $10.35 \mathrm{mg}$ $\mathrm{CH}_{4} \mathrm{~m}^{-2} \mathrm{~d}^{-1}$. This value is about $20 \%$ of the value for the Arctic tundra calculated by Whalen and Reeburgh (1990) (52 $\mathrm{mg} \mathrm{CH}_{4} \mathrm{~m}^{-2} \mathrm{~d}^{-1}$ ). The mean daily methane emissions of the wetlands in the Lena Delta amount to $16.8 \mathrm{mg} \mathrm{CH}_{4} \mathrm{~m}^{-2} \mathrm{~d}^{-1}$. That is below the range of 40 to $50 \mathrm{mg}$ $\mathrm{CH}_{4} \mathrm{~m}^{-2} \mathrm{~d}^{-1}$ estimated by Christensen et al. (1995) for northern wetlands. Earlier estimates have been much higher, for example the calculation by Matthews and Fung (1987) of about $200 \mathrm{mg} \mathrm{CH}_{4} \mathrm{~m}^{-2} \mathrm{~d}^{-1}$.

The methane emissions presented here are based on measurements in the period from June to October. We did not measure during the whole winter time. We assume that the methane emission during the cold season is nearly zero due to the low temperatures. This assumption is based on measurements in October, which show the methane emission rates decreasing to zero (Ganzert et al., 2004). The discussion about the amount of methane emitted in winter is still ongoing. Winter methane fluxes have been estimated only in North America and West Siberia (Whalen \& Reeburgh, 1988; Dise, 1992; Melloh \& Crill, 1996; Panikov \& Dedysh, 2000). The reported winter emission rates amounted from about 4 to $41 \%$ of the annual methane fluxes. Zimov et al. (1997) demonstrated that methane is produced in Arctic lakes under ice during winter. The gas is largely released to the atmosphere from holes in the ice during winter or during water column circulation after the ice melt in spring. According to Zimov et al. (1997), the north Siberian lakes could release about $75 \%$ of their annual methane emission during winter. Christensen et al. (1995) underline that the methane emissions in winter are not well investigated and that they may contribute significantly to the total emission from permafrost environments.

However, the results of a study by Worthy et al. (2000) in the Hudson Bay Lowland support our observations that the largest emissions occur in July and August decrease in September and become very weak in October. The emissions become observable again in June and are around zero or negative in the winter period.

The annual methane emission of the Lena Delta amounts to about $0.03 \mathrm{Tg}$. The emissions presented here are very conservative and most probably underestimate the annual gas release since we chose very conservative values for classes that were not measured directly in the Lena Delta and did not include possible emissions during the winter due to lacking base data. A comparison of the annual methane emission of the Lena Delta with those of other study sites is difficult due to lacking upscaling efforts of the methane emissions from measurement sites to larger study areas.

\section{Conclusions}

The results of this study show that remote sensing and supervised image classification are excellent tools to provide a base for the upscaling of local methane emission measurements in high-latitude landscapes. The supervised classification of the Landsat 7 ETM+ images is particularly suitable for detection of ecosystem types in the Lena Delta. The methane emission of tundra environments is influenced by numerous factors, e. g. microrelief, soil moisture, temperature, amount and quality of organic matter, thickness of active layer, availability of oxygen and nutrients, and vegetation. The tundra land cover type is directly or indirectly influenced by these parameters, enabling the correlation of local methane measurements with land cover classes and the upscaling of emission rates to the entire Lena Delta. The applied supervised minimum distance classification was very effective with the few ancillary data that were available for training site selection. It is possible to easily adapt our land cover classes and the Lena Delta methane budget to new field data that will become available during the ongoing research efforts in the Lena Delta ecosystem.

The three main river terraces of the Lena Delta were found to have different associations of land cover classes. The first terrace is characterised by wet sites and lakes, the second terrace appears to be drier and differs also in vegetation, and the third terrace is dominated by moist sites. Accordingly, the first terrace has the highest methane emission potential. There is a strong variation in between the individual land cover classes regarding the methane emissions. The methane emissions of the classes in the Lena Delta are within the currently known natural range of emissions from tundra sites. Taking our multi-scale approach into account, the methane source strength of certain tundra wetland types is expected to be lower than calculations based on coarser scales. This study is the first attempt to assess the methane emission of the Lena Delta based on satellite data and field measurements. Although there is still large potential for intensifying research on resolving uncertainties of methane measurements for different land cover types, on the estimation of variability of emissions from sub-class features, and on expanding emission measurements to all classes in the field, our results suggest that the Lena Delta contributes significantly to the global methane emission because of its extensive wetland areas.

The approach we used for the balance of methane emission contributes to the improvement of the global balance of methane emissions.

\section{Acknowledgments}

The authors wish to thank the Russian-German field parties during several expeditions to the Lena Delta since 1998. Special thanks go to all our Russian partners, in particular Dimitry Yu. Bolshiyanov (Arctic Antarctic Research Institute), Alexander Yu. Dereviagin (Moscow State University), Mikhail N. Grigoriev (Permafrost Institute Yakutsk), Dmitri V. Melnitschenko (Hydro Base Tiksi) and Alexander Yu. Gukov (Lena Delta Reserve). Many thanks go to Lars Kutzbach for critical reading of an early version of the manuscript. We are also very grateful to the detailed and constructive comments of four anonymous reviewers.

\section{References}

Are, F., \& Reimnitz, E. (2000). An overview of the Lena Delta setting: Geology, tectonics, geomorphology, and hydrology. Journal of Coastal Research, 16, 1083-1093.

Bartlett, K. B., Crill, P. M., Sass, R. L., Harriss, R. C., \& Dise, N. B. (1992). Methane emissions from tundra environments in the Yukon-Kuskokwim Delta, Alaska. Journal of Geophysical Research, 97, 16645-16660.

Bartlett, K. B., \& Harriss, R. C. (1993). Review and assessment of methane emissions from wetlands. Chemosphere, 26, 261-320.

Boike, J., Wille, C., \& Abnizova, A. (2008). Climatology and summer energy and water balance of polygonal tundra in the Lena River Delta, Siberia. Journal of Geophysical Research, 113. doi:10.1029/2007JG000540 
Brook, R. K., \& Kenkel, N. C. (2002). A multivariate approach to vegetation mapping of Manitoba's Hudson Bay Lowlands. International Journal of Remote Sensing, 23, 4761-4776.

Chavez, P. S. (1996). Image-based atmospheric corrections - Revised and improved. Photogrammetric Engineering E Remote Sensing, 62, 1025-1036.

Christensen, T. R. (1993). Methane emission from Arctic tundra. Biogeochemistry, 21, 117-139.

Christensen, T. R., Friborg, T., Sommerkorn, M., Kaplan, J., Illeris, L., Soegaard, H., et al. (2000). Trace gas exchange in a high-arctic valley, 1. Variations in $\mathrm{CO}_{2}$ and $\mathrm{CH}_{4}$ flux between tundra vegetation types. Global Biogeochemical Cycles, 14, 701-713.

Christensen, T. R., Jonasson, S., Calleghan, T. V., \& Havström, M. (1995). Spatial variation in high-latitude methane flux along a transect across Siberian and European tundra environments. Journal of Geophysical Research, 100, 21035-21045.

Cihlar, J. (2000). Land cover mapping of large areas from satellites: Status and research priorities. International Journal of Remote Sensing, 21, 1093-1114.

Congalton, R. G. (1991). A review of assessing the accuracy of classifications of remotely sensed data. Remote sensing of Environment, 37, 35-46.

Corradi, C., Kolle, O., Walter, K., Zimov, A., \& Schulze, E. -D. (2005). Carbon dioxide and methane exchange of a north-east Siberian tussock tundra. Global Change Biology, $11,1910-1925$.

Dise, N. B. (1992). Winter fluxes of methane from Minnesota peatlands. Biogeochemistry, 17, 71-83.

Ferguson, R. S. (1991). Detection and classification of muskox habitat on Banks Island, Northern Territories, Canada, using LANDSAT Thematic Mapper data. Arctic, 44, 66-74.

Fiedler, S., Wagner, D., Kutzbach, L., \& Pfeiffer, E. M. (2004). Element redistribution along hydraulic and redox gradients of low-centered-polygons, Lena Delta, Northern Siberia. Soil Science Society of America Journal, 68, 1004-1011.

Frey, K. E., \& Smith, L. C. (2007). How well do we know northern land cover? Comparison of four global vegetation and wetland products with a new ground-truth database for West Siberia. Global Biogeochemical Cycles, 21, GB1016. doi:10.1029/ 2006GB002706

Ganzert, L., Zimmermann, U., \& Wagner, D. (2004). Microbial process studies on methane fluxes from permafrost environments. In L. Schirrmeister, M. N. Grigoriev, L. Kutzbach, D. Wagner, \& D. Yu. Bolshiyanov (Eds.), Russian-German cooperation system Laptev Sea: The expedition Lena-Anabar 2003. Reports on Polar and Marine Research, Vol. 489. (pp. 20-29).

Grigoriev, M. N. (1993). Cryomorphogenesis in the Lena Delta (pp. 176). Yakutsk: Permafrost Institute Press (in Russian).

Gross, M. F., Hardinsky, M. A., Doolittle, J. A., \& Klemas, V. (1990). Relationships among depth to frozen soil, soil wetness, and vegetation type and biomass in tundra near Bethel, Alaska, USA. Arctic and Alpine Research, 22, 275-282.

Grosse, G., Schirrmeister, L., \& Malthus, T. J. (2006). Application of Landsat-7 satellite data and a DEM for the quantification of the thermokarst-affected terrain types in the periglacial Lena-Anabar coastal lowland. Polar Research, 25, 51-67.

Heikkinen, J. E. P., Virtanen, T., Huttunen, J. T., Elsakov, V., \& Martikainen, P. J. (2004). Carbon balance in East European tundra. Global Biogeochemical Cycles, 18, GB1023. doi:10.1029/2003GB002054

Hubberten, H. -W., Wagner, D., Pfeiffer, E. -M., Boike, J., \& Gukov, A. (2006). The RussianGerman research station Samoylov, Lena Delta: A key site for polar research in the Siberian Arctic. Polarforschung, 73, 111-116.

IPCC (2001). In J. T. Houghton, Y. Ding, D. J. Griggs, M. Nogner, P. J. van der Linden, X. Dai, K. Maskell, \& C. A. Johnson (Eds.), Climate change 2001: The scientific basis. Contribution of the working group I to the third assessment report of the Intergovernmental Panel on Climate Change. (pp. 881). Cambridge, New York: Cambridge University Press.

Joria, P. E., \& Jorgenson, J. C. (1996). Comparison of three methods for mapping tundra with Landsat digital data. Photogrammetric Engineering \& Remote Sensing, 62, 163-169.

Kienast, F., \& Tsherkasova, J. (2001). Comparative botanical recent-studies in the Lena Delta. In V. Rachold, \& M. N. Grigoriev (Eds.), Russian-German cooperation system Laptev Sea 2000: The expedition Lena 2000. Reports on Polar and Marine Research, Vol. 388. (pp. 24-44).

King, J. Y., Reeburgh, W. S., \& Regli, S. K. (1998). Methane emission and transport by arctic sedges in Alaska: Results of a vegetation removal experiment. Journal of Geophysical Research, 103, 29083-29092.

Kling, G. W., Klipphut, G. W., \& Miller, M. C. (1992). The flux of $\mathrm{CO}_{2}$ and $\mathrm{CH}_{4}$ from lakes and rivers in arctic Alaska. Hydrobiologia, 240, 23-36.

Kutzbach, L., \& Kurchatova, A. (2002). Methane-related investigations of soils and waters in the Sanga-Dzhie region. In E. -M. Pfeiffer, \& M. N. Grigoriev (Eds.), Russian-German cooperation system Laptev Sea 2000: The expedition Lena 2001.Reports on Polar and Marine Research, Vol. 426. (pp. 76-87).

Kutzbach, L., Stoof, G., \& Kurchatova, A. (2003). The flora of Samoylov Island Documentation. In M. N. Grigoriev, V. Rachold, D. Yu. Bolshiyanov, E. -M. Pfeiffer, L. Schirrmeister, D. Wagner, \& H. -W. Hubberten (Eds.), Russian-German Cooperation System Laptev Sea: The expedition Lena 2002. Reports on Polar and Marine Research, Vol. 466. (pp. 58-63)

Kutzbach, L., Wagner, D., \& Pfeiffer, E. -M. (2004). Effect of microrelief and vegetation on methane emission from wet polygonal tundra, Lena Delta, Northern Siberia. Biogeochemistry, 69, 341-362.

Le Mer, J., \& Roger, P. (2001). Production, oxidation, emission and consumption of methane by soils: A review. European Journal of Soil Biology, 37, 25-50.

Liebner, S., \& Wagner, D. (2007). Abundance, distribution and potential activity of methane oxidising bacteria in permafrost soils from the Lena Delta, Siberia. Environmental Microbiology, 9, 107-117.

MacDonald, J. A., Fowler, D., Hargreaves, K. J., Skiba, U., Leith, I. D., \& Murray, M. B. (1998). Methane emission rates from a northern wetland; response to temperature, water table and transport. Atmospheric Environment, 32, 3219-3227.
Martens, C. S., Kelley, C. A., Chanton, J. P., \& Showers, W. J. (1992). Carbon and hydrogen isotopic characterization of methane from wetlands and lakes of the YukonKuskokwim Delta, Western Alaska. Journal of Geophysical Research, 97, 16689-16701.

Matthews, E. (2000). Wetlands. In M. A. K. Khalil (Ed.), Atmospheric methane, its role in the global environment 202-233: Springer.

Matthews, E., \& Fung, I. (1987). Methane emission from natural wetlands: Global distribution, area, and environmental characteristics of sources. Global Biogeochemical Cycles, 1, 61-86.

Melloh, R. A., \& Crill, P. M. (1996). Winter methane dynamics in a temperate peatland. Global Biogeochemical Cycles, 10, 247-254

Mitsch, W. J., Mitsch, R. H., \& Turner, R. E. (1994). Wetlands of the Old and New Worlds Ecology and management. In W. J. Mitsch (Ed.), Global wetlands: Old World and New (pp. 3-56). Amsterdam: Elsevier Science.

Morrissey, L. A., \& Livingston, G. P. (1992). Methane emissions from Alaska arctic tundra: an assessment of local spatial variability. Journal of Geophysical Research, 97, 16661-16670.

Morgenstern, A. (2005). GIS based analysis of the morphometry and spatial distribution of lakes in the Lena Delta, NE-Siberia. Unpublished Diploma thesis, University of Potsdam, 70pp (in German).

Muller, S. V., Racoviteanu, A. E., \& Walker, D. A. (1999). LANDSAT MSS-derived landcover map of Northern Alaska: Extrapolation methods and a comparison with photo-interpreted and AVHRR-derived maps. International Journal of Remote Sensing, 20, 2921-2946.

Nakano, T., Kuniyoshi, S., \& Fukuda, M. (2000). Temporal variation in methane emission from tundra wetlands in a permafrost area, northeastern Siberia. Atmospheric Environment, 34, 1205-1213.

Panikov, N. S., \& Dedysh, S. N. (2000). Cold season $\mathrm{CH}_{4}$ and $\mathrm{CO}_{2}$ emission from boreal peat bogs (West Siberia): Winter fluxes and thaw activation dynamics. Global Biogeochemical Cycles, 14, 1071-1080.

Rees, W. G., Williams, M., \& Vitebsky, P. (2003). Mapping land cover change in a reindee herding area of the Russian Arctic using LANDSAT TM and ETM+ imagery and indigenous knowledge. Remote Sensing of Environment, 85, 441-452.

Richards, J.A. \& Jia, X. (1999). Remote sensing digital image analysis. An Introduction., 3. Edt., Springer, Berlin, Heidelberg, New York, 363.

Romanovskii, N. N., \& Hubberten, H. -W. (2001). Results of permafrost modelling of the lowlands and shelf of the Laptev Sea Region, Russia. Permafrost and Periglacial Processes, 12, 191-202.

Schirrmeister, L., Grosse, G., Schwamborn, G., Andreev, A. A., Meyer, H., Kunitsky, V. V., et al. (2003). Late Quaternary history of the accumulation plain north of the Chekanovsky ridge (Lena Delta, Russia): A multidisciplinary approach. Polar Geography, 27, 277-319.

Schwamborn, G., Rachold, V., \& Grigoriev, M. N. (2002). Late Quaternary sedimentation history of the Lena Delta. Quaternary International, 89, 119-134.

Semiletov, I. P. (1999). Aquatic sources and sinks of $\mathrm{CO}_{2}$ and $\mathrm{CH}_{4}$ in the polar regions. Journal of the Atmospheric Sciences, 56, 286-306.

Semiletov, I. P., Pipko, I. I., Pivovarov, N. Ya., Popov, V. V., Zimov, S. A., Voropaev, Yu. V., et al (1996). Atmospheric carbon emission from north Asian lakes: A factor of global significance. Atmospheric Environment, 30, 1657-1671.

Solomonov, N. G., Alexeyev, W. G., Lazarev, I. K., Suckow, M., Gennhardt, T., \& Knapp, T., et al. (Eds.). (1998). The reception of the Lena Delta in the list of WWF Yakutsk Tiksi. (in Russian).

Spott, O. (2003). Polygonal tundra lakes and their function as sources of atmospheric methane. Unpublished Diploma thesis, University of Leipzig, 137pp (in German).

Story, M., \& Congalton, R. G. (1986). Accuracy assessment: A user's perspective. Photogrammetric Engineering and Remote Sensing, 52, 835-841.

Stow, D., Hope, A., Boynton, W., Phinn, S., Walker, D., \& Auerbach, N. (1998). Satellitederived vegetation index and cover type maps for estimating carbon dioxide flux for arctic tundra regions. Geomorphology, 21, 313-327.

Takeuchi, W. Tamura, M. \& Yasuoka, Y (2003). Estimation of methane emission from West Siberian wetland by scaling technique between NOAA AVHRR and SPOT HRV. Remote Sensing of Environment, 85, 21-29.

Van der Molen, M. K., van Huissteden, J., Parmentier, F. J. W., Petrescu, A. M. R., Dolman, A. J., Maximov, T. C., et al. (2007). The growing season greenhouse gas balance of a continental tundra site in the Indigirka lowlands, NE Siberia. Biogeosciences, 4, 985-1003.

Virtanen, T, Mikkola, K. \& Nikula, A. (2004). Satellite image based vegetation classification of a large area using limited ground reference data: A case study in the Usa Basin, north-east European Russia. Polar Research, 23, 51-66.

Wagner, D. (2008). Microbial communities and processes in Arctic permafrost environments. In P. Dion \& C. S. Nautiyal (Eds.), Microbiology of extreme soilsSoil Biology, Vol. 13. (pp. 133-154) Berlin: Springer.

Wagner, D., Gattiner, A., Embacher, A., Pfeiffer, E. -M., Schloter, M., \& Lipski, A. (2007) Methanogenic activity and biomass in Holocene permafrost deposits of the Lena Delta, Siberian Arctic and its implication for the global methane budget. Global Change Biology, 13, 1089-1099.

Wagner, D., Kobabe, S., Pfeiffer, E. -M., \& Hubberten, H. -W. (2003). Microbial controls on methane fluxes from a polygonal tundra of the Lena Delta, Siberia. Permafrost and Periglacial Processes, 14, 173-185.

Wagner, D., Lipski, A., Embacher, A., \& Gattinger, A. (2005). Methane fluxes in extreme permafrost habitats of the Lena Delta: Effects of microbial community structure and organic matter quality. Environmental Microbiology, 7, 1582-1592.

Walter, K. M., Zimov, S. A., Chanton, J. P., Verbyla, D., \& Chapin, F. S., III (2006). Methane bubbling from Siberian thaw lakes as a positive feedback to climate warming. $\mathrm{Na}$ ture, 443, 71-75.

Whalen, S. C., \& Reeburgh, W. S. (1988). A methane flux time series for tundra environments. Global Biogeochemical Cycles, 2, 399-409.

Whalen, S. C., \& Reeburgh, W. S. (1990). A methane flux transect along the trans-Alaska pipeline haul road. Tellus, 42(B), 237-249. 
Whalen, S. C., Reeburgh, W. S., \& Reimers, C. E. (1996). Control of tundra methane emission by microbial oxidation. In J. F. Reynolds \& J. D. Tenhunen (Eds.), Landscape function and disturbance in Arctic tundraEcological studies, Vol. 120. (pp. 257-274) Berlin: Springer.

Worthy, D. E. J., Levin, I., Hopper, F., Ernst, M. K., \& Trivett, N. B. A. (2000). Evidence for a link between climate and northern wetland methane emissions. Journal of Geophysical Research, 105, 4031-4038.
Wuebbles, D. J., \& Hayhoe, K. (2002). Atmospheric methane and global change. Earthscience Reviews, 57, 177-210.

WWIS (2004). World Weather Information Service. http://worldweather.org/107/c01040. htm

Zimov, S. A., Voropaev, Y. V., Semiletov, I. P., Davidov, S. P., Prosiannikov, S. F., Chapin, F. S., III, et al. (1997). North Siberian lakes: A methane source fueled by Pleistocene carbon. Science, 277, 800-802. 